\title{
FDI and Economic Growth: Does WTO Accession and Law Matter Play Important Role in Attracting FDI? The Case of Viet Nam
}

\author{
Nguyen Dinh Chien ${ }^{1,2}$, Zhang Ke Zhong ${ }^{1} \&$ Tran Thi Giang ${ }^{1,2}$ \\ ${ }^{1}$ School of Management, Huazhong University of Science and Technology, Hubei province, Wuhan city, China \\ ${ }^{2}$ College of Economics, Hue University, Hue city, Vietnam \\ Correspondence: Nguyen Dinh Chien, School of Management, Huazhong University of Science and Technology, \\ Hubei Province, Wuhan City, China. E-mail: chienkttdhh@yahoo.com
}

\author{
Received: June 6, $2012 \quad$ Accepted: July 13, $2012 \quad$ Online Published: July 20, 2012 \\ doi:10.5539/ibr.v5n8p214 URL: http://dx.doi.org/10.5539/ibr.v5n8p214
}

\begin{abstract}
This study focused on the impact of FDI on economic growth in the entire of Vietnam and in the provinces which are ranked differently on socio - economic conditions. Based on a panel dataset of 64 provinces and cities in Vietnam and used the fixed - effects estimation method for econometric models, the empirical results show that FDI has a positive impact on economic growth of Vietnam in the period $2000-2010$. This effect in the provinces with better socio - economic conditions was stronger than in the provinces with worse socio- economic conditions. Promulgating Unified Enterprises and amending Investment Law in 2005 as well as accessing to WTO in 2007 have affected positively in attracting FDI in the period 2006 - 2010. However Law factor has a more positive and stronger impact on FDI attraction of Vietnam than WTO accession. In addition, the study examines the impact of FDI on economic growth by different regions in Vietnam. The results show that FDI has a positive impact on economic growth only exists in 4 of 6 regions of Vietnam in the period $2000-2010$.
\end{abstract}

Keywords: FDI, GDP, economic growth, Vietnam, WTO, Law

\section{Introduction}

In the current period of severe economic competition, rapid and sustainable growth has posed many challenges for the countries in the world. In this context, FDI flows are considered as the effectively supportive capital that has contributed to the national growth and development, especially in developing countries. Many countries therefore try their best to attract as many different FDI as possible. Financial competition has occurred among not only countries but also provinces within a nation as well in order to get the FDI for themselves. It leads to the fact that Vietnam is not out of that trend and (Sundaram, 2009) argues that to meet its development objectives Vietnam has to choice in attracting FDI.

Since the 1986 "Open-door" policy, Vietnam has been improving its investment environment to attract more and more foreign direct investment and this country had its FDI in 1988. The first amount of FDI capital however was not been officially disbursed until 1991. Total implemented FDI capital reached 19.5 billion dollars during the period 1991-2000; however this FDI flow really increased dramatically in the period from 2001 to 2010 with total implemented FDI capital was up to 58.5 billion dollars. It is almost three times higher in comparison with the previous period. It can be observed that within the twenty years from 1991 to 2010) the number of projects has increased from 152 to 1.237 projects, and the implemented FDI capital also soared from 328.8 million dollars to 11.0 billion dollars.

It was found that the benefits that FDI brings to host countries were contributed by several previous researches on various aspects such as FDI contributes to economic growth, technology transfer, knowledge, management skill, labor skills, employment and so on. There have been some researches done in the field of FDI and economic growth in Vietnam (Thu, 2010; Batten \&Vinh, 2009; Vu, 2008; Lan, 2006). In general, their results show that FDI has had positive effects on the national economic growth but it seems that their contributions are still limited. In an attempt, this study generally tries to explore the impact of foreign investment on Vietnam's economic growth during the period $2000-2010$ by asking the following question.

"Are there positive and strong impacts of foreign direct investment on economic growth in Vietnam?" In specific, this paper will extend the models to answer that question in the other localities which are ranked 
differently in order to ensure a fuller reflection the role of FDI in Vietnam's growth during the period of 2000 2010. This period was selected to analyze because it has important significance in implementing the 10 - year socio - economic development strategy from 2001 - 2010 that will lead Vietnam basically to become an industrialization and modernization country by the year 2020. This is also the period which foreign investment attraction has been paid special attention by Vietnamese government.

In 2000, on the other hand, the information technology used for gathering and processing statistical data was first fully put in use in all cities and provinces of Vietnam. So, the data reliability which was very high in this period helped more relevant experimental results than the previous studies. Moreover, the fact that Vietnam became the official member of WTO in 2007 would offer it a deeper and wider international economic integration. With more incentive and flexible orientation in the promulgation of Unified Enterprise Law together with the amendment in investment Law in 2005 offered many freer paths for foreign investors in Vietnam, this leads to a problem that "How WTO accession and Law amendment have impacts on the FDI attraction in Vietnam in general and in the provinces which were differently ranked on socio-economic conditions in particular?" These are the problems that this study needs to explore.

\section{Literature Review}

Relationship between FDI and economic growth has been studied by many researchers all over the world so far. By many different approaches to the study of the relationship between FDI and GDP, they have conducted studies not only within one nation but also in other regions or continents. Authors have made conclusions consistently with each other, but conclusions of others are not the same even contradictory.

According to (Sajid Anwara \& Lan, 2006) concluded that mutually reinforcing two - way linkage between FDI and economic growth exists in Vietnam. FDI effects directly and positively on GDP in the period 1996 - 2005 and its impacts on economic growth in Vietnam will be larger if more resources are invested in education and training, financial market development and in reducing the technology gap between the foreign and local firms. Agreeing with this verdict, (Srinivasan, P. et al., 2010) also indicated that there is a bidirectional relationship between FDI and GDP in Vietnam. To examines the bi-directional connection between FDI and economic growth in Cameroon for the period (1980 - 2009), (Zengkui Kang, 2010) confirmed that the positive link between FDI and economic growth and external resources are more efficient than domestic investment for economic growth. By using time-varying coefficients in an augmented production function and let FDI indirectly affect GDP growth through labor productivity. (Vu, 2008) shown that FDI has significant and positive effect economic growth in Vietnam, but the effect is not equally distributed among economic sectors.

By using the panel data model across 61 provinces and cities of Vietnam in the period 1995 to 2006, (Thu, 2010) shown that there is a strong and positive effect of FDI on economic growth in Vietnam. (Anh, 2003) proved that FDI contribution to growth was estimated to be about $7 \%$ out of $37 \%$ of total capital contribution to growth in the period 1988 - 2002. FDI has the positive relation with domestic investment and economic growth and FDI generates both significantly positive short-run and long-run impacts on economic growth in Vietnam. (R. Ledgerwood, 2010) explored the hypothesis that foreign direct investment can promote growth in developing countries and he indicated that FDI has positive and significant effect on economic growth in 85 developing countries covering Asia, Africa, and Latin America and the Caribbean for the period 1980 - 2007. (Charlton, 2007) found that the growth effects of FDI increase when we account for the quality of FDI.

To study the relationship between FDI and economic growth in Malaysia for the period 1970 - 2005 by using time series data. (Har Wai Mun et al., 2008) shown that there is a significant relationship between economic growth and FDI in Malaysia. FDI has direct positive impact on GDP, which FDI rate increase by $1 \%$ will lead to the growth rate increase by $0.046072 \%$. Basing on the statistical data of $2000-2008$ year, covering 31 provinces of panel data, the aim to analyze and estimate the relationship between FDI and the provincial gross domestic product growth rate. (Zhang-Liang MA, 2010) found that FDI inflows on regional economic growth greatly influence an increase of 1 percentage point per input, it will promote economic growth of 4.8 percentage points. Increase in investment in fixed assets also promote the region's Economic growth, an increase of 1 percentage point per input, it will promote economic growth by 1.2 percentage points.

According to (Kim \& Bang, 2008) examined relationships between FDI and economic growth in Ireland. They indicated that FDI, domestic capital, and trade are statistically significant in both the long - run and the short run, having positive effects on economic growth in this country. They also found that there is a bi-directional Granger causality between GDP and FDI, therefore FDI - led growth. By raising question as whether or not there is effect of FDI on economic growth of 62 countries covering during period of 1975 to 2000, (Wu Jyun et al., 
2008) found that FDI alone plays an ambiguous role in contributing to economic growth. FDI have a positive and significant impact on growth when host countries have better levels of initial GDP and human capital.

(Oyatoye, E. O, et al., 2011) study examines the possible impact and relationship between FDI and Economic Growth in Nigeria in the period 1987 - 2006. They concluded that there is a positive relationship between FDI and GDP, one Naira increase in the value of FDI will lead to Naira 104.749 increase in GDP. By examining the causal relationship between FDI and economic growth for three developing countries the period $1969-2000$, namely Chile, Malaysia and Thailand, based on the Toda - Yamamoto test for causality, (Chowdhury \& Mavrotas, 2005) found that GDP is causes of FDI in the case of Chile and not vice versa, while for both Malaysia and Thailand, there is a strong evidence of a bi-directional causality between FDI and GDP. Besides, (Athukorala, 2003) indicated that no robust link between FDI and growth in Sri Lanka. By empirical investigating the relationship between U.S. foreign direct investments and economic growth in the 4 ASEAN countries of Malaysia, Indonesia, Thailand, and the Philippines, Nwala (2008) shown that a negative relationship exists between the 4 ASEAN countries' economic growth and the US foreign direct investments. FDI can be growth enhancing, if it complements domestic investment. To examines the relationship between FDI and economic growth in Shaan Xi- China. (Wang Shaobin \& Wang Zhemin, 2010) shown that FDI played a certain role but not the main character in promoting economic growth, expansion of foreign direct investment scale could promote economic growth. Meanwhile, according to (Tang et al., 2008) indicated that there is only a single - directional causality from FDI to domestic investment and to economic growth but there is a bi-directional causality between domestic investment and economic growth in China for the period 1988 - 2003.

By investigating the effect of FDI on economic growth of 132 countries for the period 1995 to 2008, (Okada, et al., 2010) found that although FDI alone does not promote economic growth, it has a significant effect on economic growth if the interaction term between FDI and corruption is considered. (Magnus, et al., 2006) examines the long-run impact of FDI and trade on economic growth in Ghana. They indicated the impact of FDI on growth to be negative. By examining the effectiveness of foreign aid, FDI, and economic freedom for selected 28 Asian countries for the period 1998 - 2007, (Tiwari, 2011) indicated that inflow of FDI and foreign aid were significant factors negatively affecting economic growth. (Karimi and Yusop, 2006) found that FDI has indirect effect on economic growth in Malaysia in the period 1970-2005. (Nunnenkamp \& Spatz, 2003) confirmed an insignificant link between FDI and economic growth in Latin America. Thus, it can be found that although the topic of the relationship between FDI and economic growth has been studied by many researchers all over the world, its results are still mixed so far and exists many conflicting viewpoints.

\section{Overview of the Economy and FDI Inflows in Vietnam}

\subsection{Overview of Vietnam's Economy}

During 10 years of implementing the socio - economic development strategy during the period 2001- 2010. The socio-economic situations of Vietnam have positively changed, which has brought some significant accomplishments for Vietnam such as growing economy with relative speed, escaping from underdevelopment situation, joining the developing- country group which has average income level.

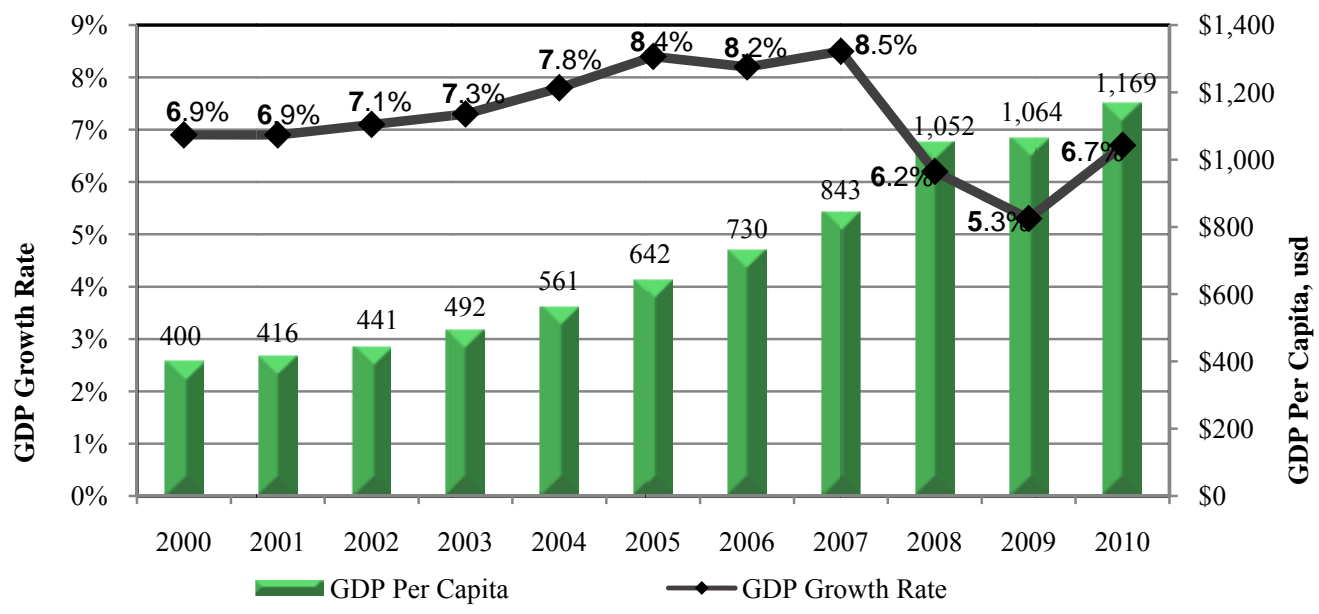

Figure 1. GDP growth and GDP per capita in the period 2000 - 2010 Source: Calculated from Statistical Yearbook of Vietnam, GSO. 
Table 1. Annual average growth rate of Vietnam

\begin{tabular}{lllll}
\hline \multirow{2}{*}{ Growth Rate } & \multirow{2}{*}{ Whole economy (\%) } & \multicolumn{3}{c}{ Of which } \\
\cline { 3 - 5 } & & Agriculture, forestry \& fisheries & Industry and Construction & Services \\
\hline Period 1991 - 2000 & 7.56 & 4.20 & 11.30 & 7.20 \\
+ Period 1991- 1995 & 8.18 & 4.09 & 12.00 & 8.60 \\
+ Period 1996 - 2000 & 6.94 & 4.30 & 10.60 & 5.75 \\
Period 2001 - 2010 & 7.26 & 3.58 & 9.09 & 7.35 \\
+ Period 2001 - 2005 & 7.51 & 3.83 & 10.25 & 6.96 \\
+ Period 2006 - 2010 & 7.01 & 3.34 & 7.94 & 7.73 \\
Period 1991 - 2010 & 7.41 & 3.89 & 10.02 & 7.28 \\
\hline
\end{tabular}

Source: Calculated from Statistical Yearbook of Vietnam, GSO.

Table 2. GDP and GNI of Vietnam in the period 2000 - 2010

\begin{tabular}{llllll}
\hline \multirow{2}{*}{ Year } & GDP, billion dong & \multicolumn{4}{l}{ GDP and GNI at average Exchange rate } \\
\cline { 2 - 6 } & At current prices & $\begin{array}{l}\text { At constant } \\
\text { 1994 prices }\end{array}$ & $\begin{array}{l}\text { GDP } \\
\text { billion, USD }\end{array}$ & $\begin{array}{l}\text { GNI } \\
\text { billion, USD }\end{array}$ & GNI per capita billion, USD \\
\hline 2000 & 441,646 & 237,600 & 31.00 & 30.80 & 396 \\
2001 & 481,295 & 292,500 & 32.00 & 32.06 & 408 \\
2002 & 535,762 & 313,300 & 35.00 & 34.52 & 433 \\
2003 & 613,443 & 336,200 & 39.00 & 39.16 & 484 \\
2004 & 715,307 & 362,400 & 45.00 & 44.50 & 550 \\
2005 & 839,211 & 393,100 & 52.00 & 51.84 & 629 \\
2006 & 974,266 & 425,400 & 60.00 & 59.42 & 713 \\
2007 & $1,143,715$ & 461,300 & 70.00 & 68.80 & 817 \\
2008 & $1,485,038$ & 490,500 & 89.00 & 86.69 & 1,018 \\
2009 & $1,658,400$ & 516,600 & 91.00 & 87.21 & 1,027 \\
2010 & $1,980,900$ & 551,600 & 101.00 & 97.40 & 1,114 \\
\hline
\end{tabular}

Source: Statistical Yearbook of Vietnam, GSO.

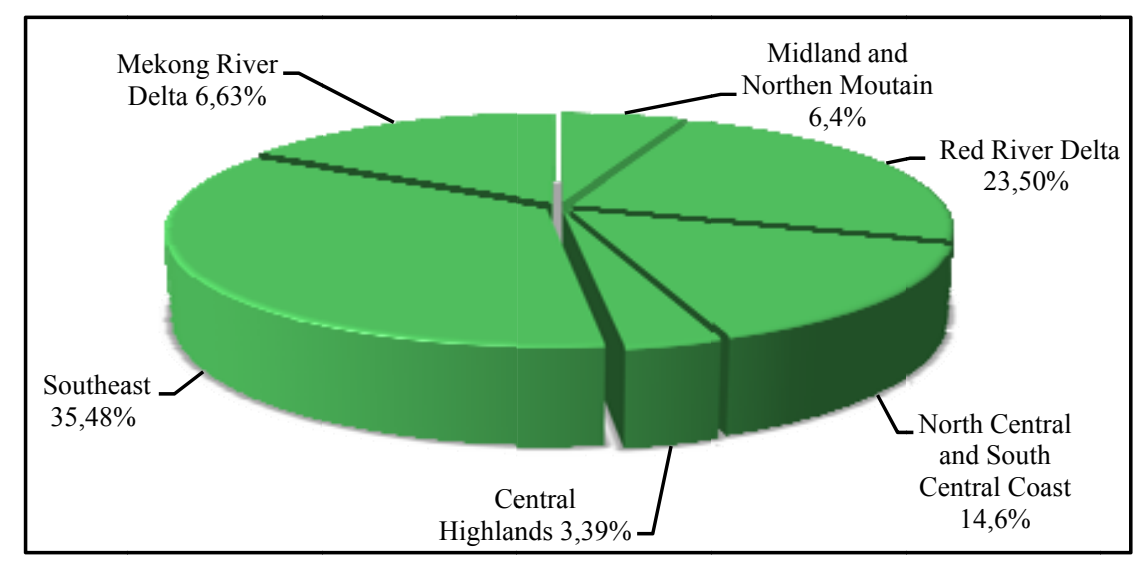

Figure 2. Share of GDP by region in the period 2000 - 2010

Source: Calculated from Statistical Yearbook of Vietnam, GSO.

Embarking on this strategy implementation, the economy of Vietnam has been not only strongly affected by the 1997 - Asian financial crisis but also negatively impacted by the 2008 - financial crisis and global economic recession. However, the annual economic growth rate of Vietnam during the past 10 years has been relatively high. The rate of the average economic growth in the period $2001-2010$ achieved $7.26 \%$, in which the growth rate in the period 2001 - 2005 and the period $2006-2010$ achieved $7.51 \% ; 7.01 \%$ respectively and the economic growth rate of Vietnam during past 20 years $(1991$ - 2010) reached $7.41 \%$ (Table 1). According to reports of the Asian Development Bank (ADB), the economic growth of Vietnam in the last 10 years was higher than the other countries as Korea, Thailand, Singapore, Indonesia, Malaysia and Philippines, only behind China and India.

Thanks to the high growth rate in the past years, GDP in 2010 was 2.32 times higher than in 2000 (in 1994 constant prices); if calculated by current prices, the GDP increased 4.4 times; if based on actual average exchange rate, the GDP increased 3.25 times. The gross national income (GNI) of Vietnam increased from 30.8 
billion dollars in 2000 to 97.40 billion dollars in 2010, equivalent to 3.15 times. This leads to the income per capita also increased from 396 dollars in 2000 to 1.114 dollars in 2010 (Table 2). According to the World Bank's income classification basing on GNI, since 2008 Vietnam have escaped from the group of low income countries and entered the average income ones. After the first decade of the 21 st century socio - economic development strategy implementation, thus, the economy of Vietnam has many positive changes, the annual economic growth rate reached $7.26 \%$ which helped Vietnam escape from less developed status, entered the group of developing countries having lower average income. Most of the key sectors and fields obtained the higher results in comparison with the period 1991 - 2000.

It can be observed that Vietnam achieved dual success in this period as GDP in 2010 increased at least two times in comparison with 2000 which made Vietnam escape from the underdevelopment situation as the target posed. Besides, the milestone that Vietnam became the 150th official member of the WTO in January 2007 after 11 years of negotiation upgraded the position of Vietnam in the international arena.

\subsection{Overview of Vietnam's FDI Inflow}

In the past 20 years, FDI has become an effectively supportive capital for economic growth and development of Vietnam. Every year, Vietnam has received thousands of foreign investment projects with a large amount of FDI disbursed which has created a mass material wealth for society and considerably contributed to the state budget.

After the Foreign Investment Law had been promulgated since1987, FDI officially flew to Vietnam with the first amount of 342 million dollars in 1988. The period 1988 - 1990 however, there were on FDI committed capital, without any implemented capital. It could be explained that when the Vietnamese Government opened its integration with the world economy, the foreign investors came to Vietnam with the purpose of exploring the market and investment environment not for a "real" investment. After the first FDI unit officially went into business and production in 1991, the shortcomings of guiding and managing this type of investment have come into being. Therefore, to match the reality, the investment Law was firstly amended in 1992. It made the registered FDI capitals increased strongly in the period 1991 - 1995 from 1.29 billion dollars to 6.94 billion dollars; the implemented FDI capital sharply grew up from 328.8 million dollars to 2.56 billion dollars. 1995 was the year which marked the recorded high economic growth rate during past 20 years of Vietnam's economy $(9.54 \%)$.

The trend of more and more diversified types of investments, along with the appearance of many international investors makes the Vietnamese Law need to be amended. So, it was amended the second time in 1996 by a more flexible direction. It leads to the issue that the implemented FDI capital from 2.71 billion dollars in 1996 increased to 3.11 billion dollars in 1997. It is said that Vietnam has emerged as an attractive and potential destination as well as investment market of the foreign investors in this period. This is demonstrated by the rapid increasing in both FDI capital and the number of projects. However, the Asian financial crisis occurred in 1997 negatively affected to the economic situation of many countries in the regions and on the world. The period 1998 - 2000, revealed the slowdown of this capital; the rate of economic growth of Vietnam also decreased dramatically in 1999 and reached a low record level 4.77\%, doubled lower than in 1995(GSO).

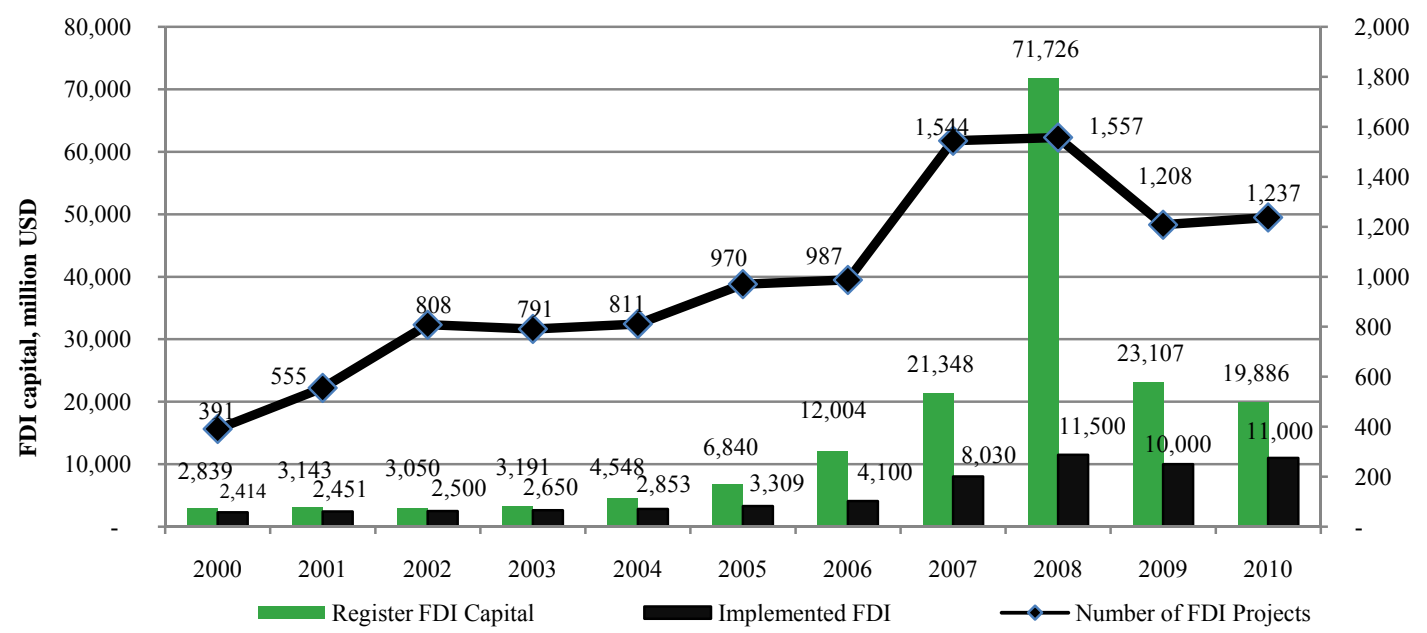

Figure 3. FDI inflow of Vietnam in the period 2000 - 2010 


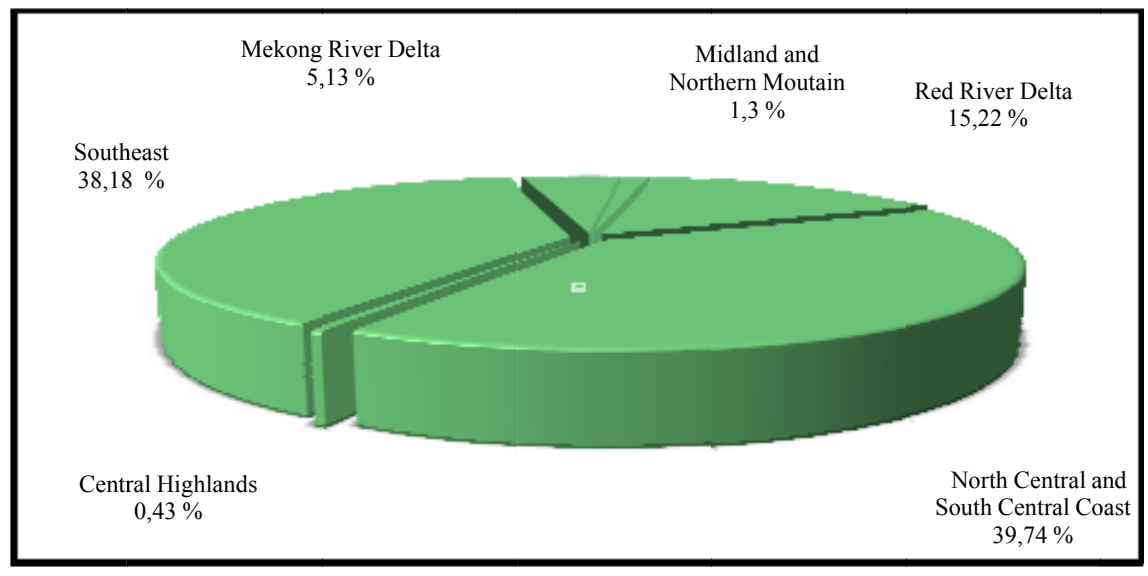

Figure 4. Share of FDI by region in the period $2000-2010$

Source: Calculated from Statistical Yearbook of Vietnam, GSO.

At the end of the year 2000, the economy showed recovery signs and began growing. In the period $2001-2005$, both of projects numbers and the registered FDI capital increased 2.5 times compared to the year 2000. The implemented FDI capital increased rapidly, from 2.45 billion in 2001 to 3.31 billion in 2005 (Figure 4). In this period, Vietnam's economy has not only recovered well after the crisis but also achieved high economic growth rate, from $6.90 \%$ in 2001 to $8.44 \%$ in 2005 . Besides, the reform administrative procedure and amended investment law in 2005, the VAT, Corporate income Tax in 2003 facilitated the project registering and investing. These modifications quickly had positive impacts on attracting FDI in Vietnam. Period 2006 - 2010 was a period that FDI inflows of Vietnam grew up strongly in both amount of registered FDI and implemented FDI capital. On the other hand, the WTO successful accession had strong positive effects on many fields of VN, especially in the foreign investment fields, FDI flows was continuously high growth. In the year 2007 registered FDI capital soared to 8.03 billion, double the figure in 2006. Although the financial crisis and global economic downturn occurred in 2008, the registered FDI flows into the VN still reached a high record since the Vietnam opened and integrate world economic. The registered FDI capitals soared to 71.0 billion dollars while the implemented FDI capital reached 11.5 billion dollars. Due to long impact of crisis until now, the FDI capitals have tended to reduce but the implemented FDI capitals still remain at high level, in the period 2008 - 2010 the average implemented FDI of each year reached 11.3 billion dollars.

In short, in the past 10 years, Vietnam's economy has faced many challenges from the negative impact of Asian financial crisis to the global economic recession in 1997 and 2008. However, in the field of foreign direct investment, Vietnam achieved many significant accomplishments, FDI inflows in Vietnam grew up strongly with average annual growth rate of $18.5 \%$. There have been more and more international investors with many types of projects in variety fields coming to Vietnam. All of the facts mentioned above have contributed to the economic growth and helped constitute the economic restructuring of Vietnam with total implemented FDI in the period 2001 - 2010 of 58.5 billion dollars, in which in the period 2001- 2005 reached 13.9 billion dollars, occupied of $66.8 \%$ and from 2006 - 2010 it reached 44.6 billion dollars, occupied of $30.1 \%$ registered FDI, respectively.

\section{Data and Methodology}

\subsection{Model}

This study focuses on answering the question whether or not there are positive and strong impacts of foreign direct investment on economic growth in Vietnam? Econometric model was built to test and to assess the research problems based on the neoclassical growth theory model as well as some previous experimental analysis models such as Barro and Sala i-Martin (2004), Lucas (1990), Romer (1987) and Mankiw (2004). The Cobb-Douglas production function is written as follows.

$$
Y=f(K, L)
$$

Y: production output or the total social product, $K$; physical capital, $L$; human capital.

International trade not only affects on economic growth but also helps the host countries specialize production. According to the new growth theory, the export expansion will improve the economy's efficiency in distributing 
input factors and lead to the growth of productivity (Mankiw, 2004). (Salvatore \& Hatcher, 1991) argued that export orientation leads to higher the productivity factor because of better exploiting the ability scale of the economy. On the other hand, it will reduce the serious constraint on foreign exchange and facilitate to access international market greater. Moreover, the international trade will lead to a higher technological innovation rate.

According to (Boriss \& Herzer, 2006) argued that export is considered as a vehicle of growth through the expansion of external demand. Besides, (Grossman \& Helpman, 1991) indicated that export can positively contribute to the economic growth through various means such as facilitating favorable conditions for exploitation of economic scale, or promoting the diffusion of technological knowledge. Therefore, the production function can be expanded by adding export variable. (Romer, 1989) indicated that financial development has a significant positive impact on economic growth. (King \& Levine, 1993) stated that the level of higher domestic investment has positively impacted on faster the economic growth and stronger capital accumulation in the future. Model 1 therefore was expanded and takes the following form.

$$
Y=f(D I, G E, F D I, L, E X)
$$

\section{I: Domestic investment, GE: Government spending, EX: Exports.}

To answer the question mentioned above as well as to find out the significance of the explanatory variables, model which analysis empirically the impact of FDI on economic growth of Vietnam in the period $2000-2010$ is represented as follows.

$$
G D P_{i t}=\alpha_{0}+\alpha_{1} F D I_{i t}+\alpha_{2} F D I_{i(t-1)}+X \beta+\omega_{i t}
$$

Where; GDP: Gross domestic product at current prices, $X$ : Matrix; Control variables includes DMI is total domestic investment capital consists of state and private capital, GEX refers to government expenditure, TRB is trade balance, it is measured by export minus import, EXR is average exchange rate stated by State Bank of Vietnam, LGR presents growth rate of labor force, $i=1,2$ to 64 , refers to individual province of Vietnam, $t$ refers to years from 2000 to 2010 .

$$
\omega_{i t}=u_{i}+e_{i t}
$$

$u_{i}$ is time-invariant unobserved individual factors that determine the outcome, $e_{i t}$ is time-variant unobserved individual factors (idiosyncratic error) that determine the outcome. Due to the incidental parametric problem, we can't take the first difference to obtain the coefficient for time-invariant unobserved individual factors $u_{i}$. Therefore, two possibilities could affect the consistence of coefficient. If $u_{i}$ is uncorrelated with explanatory variables, the random-effect model can be achieved in estimation, However, if $u_{i}$ is violated the determination of outcome variable, in other words, they has correlation with explanatory variables, the obtained coefficients may lead to be unbiased and fixed-effect model is needed to be tackled for the solution. We decide to approach the Hausman test to detect the appropriate method for above panel data. As a result, the P-value showing below 0.05 approves the fixed-effect model. In this case, by using fixed-effect estimation, the $u_{i}$ will be eliminated across years, and the coefficient will be determined by entirely time-variant factors.

\subsection{Data}

As mentioned above, the information technology has only been used widely and fully for the collection, processing, storing the statistics data in 64 provinces and cities of Vietnam since 2000. Thus, the data we had in this period was really perfect, reliable, and strong balance panel data. Variables of GDP, XK, NK, GEX, DMI, EXR were taken from the Statistical Yearbook of 64 provinces and cities of VN provided by General Statistics Office (GSO) in the period 2000-2010, FDI variable received from the Ministry of Planning and Investment, LGR got from the Ministry of Labor Invalids and Social Affairs. All Vietnamese monetary variables are converted into USD in accordance with the annual average exchange rate. In addition, to conduct empirical analysis, this study collected several various information sources such as website of 64 provinces, Ministry of Science and Technology.

\section{Empirical Results}

\subsection{The Impact of FDI on the Economic Growth of Vietnam}

After estimating the impact of FDI on the economic growth of Vietnam and satisfying by the Hansen test and by using the fixed-effect estimation methods to test the research questions. The estimation results present in column 1 (Table 3 ) shows that the estimated coefficient of FDI is at $1 \%$ statistically significant level with ceteris-paribus. The increase of one FDI unit will make the economic growth of Vietnam increase approximately 0.1051446 dollars. It means that FDI has a positive impact on economic growth of Vietnam in the period 2000-2010 but this effect is not very strong. Besides, other factors have a positive impact on economic growth as export, 
government spending, domestic investment, FDI of previous year. The regression coefficients of these factors are statistically significant.

According to the ranking of provinces in Vietnam in accordance with its socio - economic conditions, there are two kinds of categories: the provinces with difficult socio-economic conditions ranked first $(\mathrm{PR}=1)$ and the provinces with extremely difficult socio - economic conditions ranked second $(P R=2)$. In period $2000-2010$, there were 17 provinces in whole country ranked first and 47 provinces ranked second. To test the impact of FDI on economic growth in provinces which were differently ranked.

Set Prcat $=0$ if $P R=1$; Prcat $=1$ if $P R=2$. Thus, if Prcat $=0$, it means that provinces have difficult socio economic conditions, if Prcat $=1$, the provinces have extremely difficult socio-economic conditions. The model is extended by adding the dummy variables Prcat. The result in column 2 (Table 3) shows that the estimated coefficient of FDI variables is 0.2506076 , the variable of (FDI * Prcat) is -0.179302 . Both of these coefficients are at $1 \%$ statistically significant level. It can be explained that the impact of FDI on economic growth in provinces which are ranked second (extremely difficult socio - economic conditions) is less than in the provinces which are ranked first (difficult socio - economic conditions) is 0.179302 dollars. Thus, the impact of FDI on economic growth in the provinces which are extremely difficult socio - economic conditions is less than in the provinces which have better socio - economic conditions. In other words, FDI has contributed more significantly and positively in explaining GDP in provinces with better socio-economic conditions.

\subsection{The Impact of WTO and Law Matter in Attracting FDI in Vietnam}

To test the hypothesis of how joining WTO and legal issues impact in attracting FDI in Vietnam, the model is extended to consider their interaction by adding variables (WTO * FDI) and (LAW * FDI) into the model. Estimation results in column 3 (Table 3) show that, the regression coefficient of the variable (WTO * FDI) are at $5 \%$ statistically significant level. It is implied that the WTO accession has significantly positive impact on attracting FDI in Vietnam in the period 2007- 2010. On the other hand, the result also indicates that after joining the WTO, FDI has a more positive and stronger impact on the Vietnamese economic growth than in the previous period.

Examining this effect in the provinces which are differently ranked, variable (FDI * WTO * Prcat) is added to the model. According to the results in column 4 (Table 3), it indicates that the regression coefficient of the variable (WTO * FDI * Prcat) is -0.1855055 at $1 \%$ statistically significant level. This illustrates that the impact of WTO accession on attracting FDI in the provinces ranked second is lower than provinces ranked first by 0.1855055 dollars. Thus, after joining the WTO, the amount of FDI capital has grown rapidly in VN and the impact of WTO accession on attracting FDI in the provinces ranked second is less than in provinces ranked first.

It is also similarly to the legal issues. Estimation results in column 5 (Table 3) reveals that the regression coefficients of the variable (LAW * FDI) is 0.5675031 at $1 \%$ statistically significant level. This can prove that promulgating the unified enterprises law and amending the investment law of Vietnam by a direction of more flexible, more preferential and non-discriminatory domestic or foreign investors have positive and strong impact on attracting FDI in Vietnam in the period 2005 - 2010.

Considering the influence of this factor in attracting FDI in the provinces which are differently ranked, the variable of (FDI * LAW * Prcat) is added to the model. The results presented in column 6 (Table 3 ) show that estimated coefficients of the variable (FDI * LAW * Prcat) is -0.1477234 , at $1 \%$ statistically significant level. It can be observed that after promulgating of the Unified Enterprises Law and modifying the Investment Law, FDI attraction in the provinces ranked second is less than the provinces ranked first by 0.1477234 dollars. Thus, after issuing a Unified Enterprise and amending Investment Law in 2005, the amount of FDI capital has grown strongly in Vietnam and its influences on the provinces with extremely difficult socio economic conditions is less than the provinces with difficult economic conditions (first ranked provinces). In order to confirm whether the impact of legal issues are more active than WTO accession in attracting FDI or not, the model is extended by adding the two variables. The results in column 7 (Table 3) describe that both of these two factors have contributed positively to the growth of FDI in Vietnam. Estimated coefficients of the variable (WTO * FDI) is 0.1145248 , and the variable (LAW * FDI) is 0.5002864 at $1 \%$ statistically significant level. It indicates that the impacts of law factor on attracting FDI are more positive and stronger than WTO factor.

This reflects that the policies and goals have made by Vietnamese government to promote economic growth through FDI inflow in remote areas with extremely difficult socio - economic conditions such as Midland and Northern Mountain, North Central and Central Coast, Central Highlands has effective and positive impact in FDI attraction strategy of Vietnam. However, to attract more and more FDI than in the remote areas, especially in the localities with extremely difficult socio-economic conditions, the central and local government should be focus 
on investment infrastructure, labor skills, human capital, financial market development, develop and extend industrial zones.

In short, the promulgation of Unified Enterprise and the Investment Law amendment in 2005 as well as WTO accession in 2007 have positive impacts on attraction of FDI in Vietnam. These impacts on the provinces in first ranking are stronger than the provinces ranked second (extremely difficult socio-economic conditions) for the period 2005 - 2010. Comparison the effect of two these factors on FDI attraction, the results are found that the law factor has more positive effects than WTO factor in attracting FDI in Vietnam. Thus, it can be inferred that the policy factor requires an important role in attracting FDI in Vietnam. It leads to the problem that the policy makers of Vietnam have to pay more attention to the offering the appropriate policies to attract more FDI for the host country.

Table 3. The estimation result impact of FDI on GDP

\begin{tabular}{|c|c|c|c|c|c|c|c|}
\hline \multirow[t]{2}{*}{ Variables } & \multicolumn{7}{|c|}{ GDP - Dependent variable } \\
\hline & (1) & (2) & (3) & (4) & (5) & (6) & (7) \\
\hline $\begin{array}{l}\text { FDI - Foreign Direct } \\
\text { Investment }\end{array}$ & $\begin{array}{l}0.1051 \\
(0.019)^{* * *}\end{array}$ & $\begin{array}{l}0.2506 \\
(0.043)^{* * *}\end{array}$ & $\begin{array}{l}-0.1144 \\
(0.093)\end{array}$ & $\begin{array}{l}-0.018 \\
(0.095)\end{array}$ & $\begin{array}{l}-0.4639 \\
(0.154)^{* * *}\end{array}$ & $\begin{array}{l}-0.329 \\
(0.159)^{* *}\end{array}$ & $\begin{array}{l}-0.5126 \\
(0.159)^{* * *}\end{array}$ \\
\hline Lag FDI & $\begin{array}{l}0.04671 \\
(0.0202)^{* *}\end{array}$ & $\begin{array}{l}0.0436 \\
(0.0199)^{* *}\end{array}$ & $\begin{array}{l}0.0395 \\
(0.0203)^{*}\end{array}$ & $\begin{array}{l}0.03796 \\
(0.020)^{*}\end{array}$ & $\begin{array}{l}0.0385 \\
(0.020)^{*}\end{array}$ & $\begin{array}{l}0.03724 \\
(0.0199)^{*}\end{array}$ & $\begin{array}{l}0.0357 \\
(0.0202)^{*}\end{array}$ \\
\hline DMI - Domestic Investment & $\begin{array}{l}1.2769 \\
(0.086)^{* * *}\end{array}$ & $\begin{array}{l}1.333 \\
(0.086)^{* * *}\end{array}$ & $\begin{array}{l}1.2721 \\
(0.086)^{* * *}\end{array}$ & $\begin{array}{l}1.3274 \\
(0.085)^{* * *}\end{array}$ & $\begin{array}{l}1.2754 \\
(0.085)^{* * *}\end{array}$ & $\begin{array}{l}1.3283 \\
(0.086)^{* * *}\end{array}$ & $\begin{array}{l}1.273 \\
(0.084)^{* * *}\end{array}$ \\
\hline $\begin{array}{l}\text { GEX - Government } \\
\text { Expenditure }\end{array}$ & $\begin{array}{l}3.3715 \\
(0.226)^{* * *}\end{array}$ & $\begin{array}{l}3.1125 \\
(0.234)^{* * *}\end{array}$ & $\begin{array}{l}3.3524 \\
(0.226)^{* * *}\end{array}$ & $\begin{array}{l}3.0685 \\
(0.233)^{* * *}\end{array}$ & $\begin{array}{l}3.2351 \\
(0.226)^{* * *}\end{array}$ & $\begin{array}{l}3.0142 \\
(0.235)^{* * *}\end{array}$ & $\begin{array}{l}3.2412 \\
(0.226)^{* * *}\end{array}$ \\
\hline TRB - Trade Balance & $\begin{array}{l}0.30062 \\
(0.032)^{* * *}\end{array}$ & $\begin{array}{l}0.3266 \\
(0.032)^{* * *}\end{array}$ & $\begin{array}{l}0.3052 \\
(0.031)^{* * *}\end{array}$ & $\begin{array}{l}0.3306 \\
(0.032)^{* * *}\end{array}$ & $\begin{array}{l}0.2876 \\
(0.031)^{* * *}\end{array}$ & $\begin{array}{l}0.3129 \\
(0.032)^{* * *}\end{array}$ & $\begin{array}{l}0.2916 \\
(0.032)^{* * *}\end{array}$ \\
\hline ER-Exchange rate & $\begin{array}{l}-10.065 \\
(5.163)^{*}\end{array}$ & $\begin{array}{l}-8.080 \\
(5.133)\end{array}$ & $\begin{array}{l}-10.634 \\
(5.147)^{* *}\end{array}$ & $\begin{array}{l}-8.476 \\
(5.105)^{*}\end{array}$ & $\begin{array}{l}-7.987 \\
(5.136)\end{array}$ & $\begin{array}{l}-6.4745 \\
(5.1199)\end{array}$ & $\begin{array}{l}-8.534 \\
(5.1544)^{*}\end{array}$ \\
\hline LBG - Labor growth rate & $\begin{array}{l}2.195 \\
(2.3825)\end{array}$ & $\begin{array}{l}1.197 \\
(2.371)\end{array}$ & $\begin{array}{l}1.978 \\
(2.3744)\end{array}$ & $\begin{array}{l}0.926 \\
(2.3564)\end{array}$ & $\begin{array}{l}1.5375 \\
(2.3626)\end{array}$ & $\begin{array}{l}0.7596 \\
(2.3579)\end{array}$ & $\begin{array}{l}1.5006 \\
(2.3619)\end{array}$ \\
\hline FDI*Prcat & & $\begin{array}{l}-0.1793 \\
(0.048)^{* * *}\end{array}$ & & & & & \\
\hline (WTO*FDI) & & & $\begin{array}{l}0.2167 \\
(0.091)^{* *}\end{array}$ & $\begin{array}{l}0.2722 \\
(0.090)^{* * *}\end{array}$ & & & $\begin{array}{l}0.1145 \\
(0.096)\end{array}$ \\
\hline (WTO*FDI*Prcat) & & & & $\begin{array}{l}-0.1855 \\
(0.045)^{* * *}\end{array}$ & & & \\
\hline$(\mathrm{LAW} * \mathrm{FDI})$ & & & & & $\begin{array}{l}0.5675 \\
(0.152)^{* * *}\end{array}$ & $\begin{array}{l}0.7014 \\
(0.157)^{* * *}\end{array}$ & $\begin{array}{l}0.5003 \\
(0.162)^{* * *}\end{array}$ \\
\hline (LAW*FDI* Prcat) & & & & & & $\begin{array}{l}-0.1477 \\
(0.047)^{* * *}\end{array}$ & \\
\hline Constants & $\begin{array}{l}88974 \\
(13808)^{* * *}\end{array}$ & $\begin{array}{l}82454 \\
(14000)^{* * *}\end{array}$ & $\begin{array}{l}88926 \\
(13751)^{* * *}\end{array}$ & $\begin{array}{l}81664 \\
(13681)^{* * *}\end{array}$ & $\begin{array}{l}90504 \\
(13660)^{* * *}\end{array}$ & $\begin{array}{l}84800 \\
(13679)^{* * *}\end{array}$ & $\begin{array}{l}90297 \\
(13656)^{* * *}\end{array}$ \\
\hline No of groups & 64 & 64 & 64 & 64 & 64 & 64 & 64 \\
\hline No of Observation & 637 & 637 & 637 & 637 & 637 & 637 & 637 \\
\hline
\end{tabular}

Source: Calculated by Author; statistically significant level: ${ }^{*} \alpha=10 \%,{ }^{* *} \alpha=5 \%$ and ${ }^{* * *} \alpha=1 \%$.

\subsection{The Impact of FDI on Economic Growth in Regions of Vietnam}

Assessment on the relationship between FDI and the economic growth in the six regions of Vietnam including Red River Delta region, Midland and Northern Mountain, North Central region and Central Coast, Central Highlands, South East, Mekong River Delta. According to statistical data, it shows that FDI is not equal in the distribution between the regions in Vietnam in the period 2000 - 2010. It shows the proportion of FDI in North Central region and Central Coast and Southeast region which account for $77.92 \%$. The FDI density of 4 remaining regions accounted for only $22.8 \%$ (Figure 4). To test the hypothesis "The regions with more FDI will have more positive impacts on economic growth". Its estimation results is presented in the column 1 (Table 4) show that FDI only positively impact on the economic growth of regions as the Midland and Northern Mountain, Central Highlands region, the Southeastern region, and the Mekong Delta region. Estimated coefficients of these areas are at $5 \%$ and $10 \%$ statistically significant level. 
The surprising and contrary thing to the hypothesis is the Red River Delta and the North Central and Central Coast are the two regions accounting for a large proportion of FDI but the results do not reveal the positive impacts of FDI on the economic growth in two these regions. The Red River Delta is the key economic region of North and whole country with proportion of FDI is $15 \%$ of whole country's FDI, and the North Central region and Central Coast, FDI is accounted for $39.74 \%$ of the entire country. This again confirms that the quality of projects in these two regions is less than other regions.

\subsection{The Impact of WTO Accession and the Law in Attracting FDI by Region}

Considering the impact of promulgating Unified Enterprises Law and amending Investment Law as well as WTO accession on attracting FDI, the empirical results in column 6 (Table 5 and Table 6) show that these factors have a positive impact on attracting FDI in 3 of 6 regions, including Midland and Northern Mountain, North Central region and Central Coast and Mekong River Delta region.

There are not any found impacts of these two factors on attracting FDI in the Southeast region and the Red River Delta. This is contrary to the author's expectation that the region with better socio-economic conditions impacted by WTO accession and legal issues stronger and more positive on FDI attracting.

Table 4. Impact of FDI on GDP by region

\begin{tabular}{|c|c|c|c|c|c|c|c|c|}
\hline \multirow[t]{2}{*}{ Regions } & \multirow{2}{*}{$\begin{array}{l}\text { No. } \\
\text { Obs }\end{array}$} & \multirow[t]{2}{*}{ Cons } & \multicolumn{6}{|c|}{ GDP - Dependent Variables } \\
\hline & & & $\begin{array}{l}\text { FDI } \\
(1)\end{array}$ & $\begin{array}{l}\text { DMI } \\
(2) \\
\end{array}$ & $\begin{array}{l}\text { GEX } \\
(3)\end{array}$ & $\begin{array}{l}\text { TRB } \\
\text { (4) }\end{array}$ & $\begin{array}{l}\text { LGR } \\
\text { (5) }\end{array}$ & $\begin{array}{l}\text { EXR } \\
\text { (6) }\end{array}$ \\
\hline $\begin{array}{l}\text { Midland and } \\
\text { Northern Mountain }\end{array}$ & 154 & $\begin{array}{l}53.72 \\
(31.45)^{*}\end{array}$ & $\begin{array}{l}0.2875 \\
(0.171)^{*}\end{array}$ & $\begin{array}{l}0.470 \\
(0.084)^{* * *}\end{array}$ & $\begin{array}{l}1.351 \\
(0.125)^{* * *}\end{array}$ & $\begin{array}{l}-0.1683 \\
(0.077)^{* *}\end{array}$ & $\begin{array}{l}-1.109 \\
(0.732)\end{array}$ & $\begin{array}{l}-0.398 \\
(1.803)\end{array}$ \\
\hline Red River Delta & 129 & $\begin{array}{l}130.9 \\
(50.7)^{* * *}\end{array}$ & $\begin{array}{l}-0.0091 \\
(0.059)\end{array}$ & $\begin{array}{l}0.4469 \\
(0.096)^{* * *}\end{array}$ & $\begin{array}{l}3.3674 \\
(0.315)^{* * *}\end{array}$ & $\begin{array}{l}-0.160 \\
(0.026)^{* * *}\end{array}$ & $\begin{array}{l}5.5777 \\
(2.252)^{* *}\end{array}$ & $\begin{array}{l}-0.013 \\
(6.87)\end{array}$ \\
\hline $\begin{array}{l}\text { North Central and } \\
\text { South Central Coast }\end{array}$ & 154 & $\begin{array}{l}137.7 \\
(30.12)^{* * *}\end{array}$ & $\begin{array}{l}0.0055 \\
(0.010)\end{array}$ & $\begin{array}{l}0.749 \\
(0.09)^{* * *}\end{array}$ & $\begin{array}{l}1.3910 \\
(0.137)^{* * *}\end{array}$ & $\begin{array}{l}-0.102 \\
(0.050)^{* *}\end{array}$ & $\begin{array}{l}5.7794 \\
(4.966)\end{array}$ & $\begin{array}{l}3.6749 \\
(4.640)\end{array}$ \\
\hline Central Highlands & 55 & $\begin{array}{l}9.382 \\
(22.44)\end{array}$ & $\begin{array}{l}0.9562 \\
(0.383)^{* *}\end{array}$ & $\begin{array}{l}1.5972 \\
(0.169)^{* * *}\end{array}$ & $\begin{array}{l}-0.2166 \\
(0.351)\end{array}$ & $\begin{array}{l}1.0127 \\
(0.104)^{* * *}\end{array}$ & $\begin{array}{l}-0.3405 \\
(1.8910)\end{array}$ & $\begin{array}{l}-1.748 \\
(3.83)\end{array}$ \\
\hline Southeast & 66 & $\begin{array}{l}24.2 \\
(177.45)\end{array}$ & $\begin{array}{l}0.143 \\
(0.065)^{* *}\end{array}$ & $\begin{array}{l}1.460 \\
(0.330)^{* * *}\end{array}$ & $\begin{array}{l}4.473 \\
(0.854)\end{array}$ & $\begin{array}{l}0.681 \\
(0.045)^{* * *}\end{array}$ & $\begin{array}{l}-15.89 \\
(14.729)\end{array}$ & $\begin{array}{l}8.617 \\
(32.84)\end{array}$ \\
\hline Mekong River Delta & 143 & $\begin{array}{l}84.2 \\
(40.82)^{* *}\end{array}$ & $\begin{array}{l}0.1142 \\
(0.053)^{* *}\end{array}$ & $\begin{array}{l}0.833 \\
(0.097)^{* * *}\end{array}$ & $\begin{array}{l}3.077 \\
(0.230)^{* * *}\end{array}$ & $\begin{array}{l}0.497 \\
(0.144)^{* * *}\end{array}$ & $\begin{array}{l}0.058 \\
(2.5191)\end{array}$ & $\begin{array}{l}3.7942 \\
(4.150)\end{array}$ \\
\hline
\end{tabular}

Source: Calculated by Author; statistically significant level: ${ }^{*} \alpha=10 \%,{ }^{* *} \alpha=5 \%$ and ${ }^{* * *} \alpha=1 \%$.

Table 5. Impact of the WTO accession in attracting FDI by region

\begin{tabular}{|c|c|c|c|c|c|c|c|c|}
\hline \multirow[t]{2}{*}{ Regions } & \multirow{2}{*}{$\begin{array}{l}\text { No. } \\
\text { Obs }\end{array}$} & \multirow[t]{2}{*}{ Cons } & \multicolumn{6}{|c|}{ GDP - Dependent Variables } \\
\hline & & & $\begin{array}{l}\text { FDI } \\
(1)\end{array}$ & $\begin{array}{l}\text { DMI } \\
(2) \\
\end{array}$ & $\begin{array}{l}\text { GEX } \\
\text { (3) }\end{array}$ & $\begin{array}{l}\text { TRB } \\
(4) \\
\end{array}$ & $\begin{array}{l}\text { LGR } \\
(5) \\
\end{array}$ & $\begin{array}{l}\text { WTO*FDI } \\
\text { (6) }\end{array}$ \\
\hline $\begin{array}{l}\text { Midland and Northern } \\
\text { Mountain }\end{array}$ & 154 & $\begin{array}{l}23490 \\
(9037)^{* * *}\end{array}$ & $\begin{array}{l}-0.196 \\
(0.224)\end{array}$ & $\begin{array}{l}0.526 \\
(0.08)^{* * *}\end{array}$ & $\begin{array}{l}1.691 \\
(0.21)^{* * *}\end{array}$ & $\begin{array}{l}-0.192 \\
(0.07)^{* * *}\end{array}$ & $\begin{array}{l}-1.210 \\
(0.68)^{* * *}\end{array}$ & $\begin{array}{l}0.861 \\
(0.295)^{* * *}\end{array}$ \\
\hline Red River Delta & 129 & $\begin{array}{l}-664.3 \\
(18551)\end{array}$ & $\begin{array}{l}0.0009 \\
(0.122)\end{array}$ & $\begin{array}{l}0.6315 \\
(0.12)^{* * *}\end{array}$ & $\begin{array}{l}2.9351 \\
(0.42)^{* * *}\end{array}$ & $\begin{array}{l}-0.078 \\
(0.03)^{* *}\end{array}$ & $\begin{array}{l}6.461 \\
(2.25)^{* * *}\end{array}$ & $\begin{array}{l}0.027 \\
(0.124)\end{array}$ \\
\hline $\begin{array}{l}\text { North Central and S South } \\
\text { Central Coast }\end{array}$ & 154 & $\begin{array}{l}-70529 \\
(9829)^{* * *}\end{array}$ & $\begin{array}{l}-0.139 \\
(0.084)^{*}\end{array}$ & $\begin{array}{l}0.473 \\
(0.07)^{* * *}\end{array}$ & $\begin{array}{l}1.0461 \\
(0.11)^{* * *}\end{array}$ & $\begin{array}{l}-0.166 \\
(0.04)^{* * *}\end{array}$ & $\begin{array}{l}5.403 \\
(3.5001)\end{array}$ & $\begin{array}{l}0.141 \\
(0.083)^{*}\end{array}$ \\
\hline Central Highlands & 55 & $\begin{array}{l}12433 \\
(15563)\end{array}$ & $\begin{array}{l}-0.441 \\
(1.54)\end{array}$ & $\begin{array}{l}1.110 \\
(0.18)^{* * *}\end{array}$ & $\begin{array}{l}0.6448 \\
(0.44)\end{array}$ & $\begin{array}{l}1.0292 \\
(0.16)^{* * *}\end{array}$ & $\begin{array}{l}-0.8844 \\
(1.6550)\end{array}$ & $\begin{array}{l}0.987 \\
(1.453)\end{array}$ \\
\hline Southeast & 66 & $\begin{array}{l}-2858 \\
(66796)\end{array}$ & $\begin{array}{l}0.0129 \\
(0.2123)\end{array}$ & $\begin{array}{l}1.650 \\
(0.43)^{* * *}\end{array}$ & $\begin{array}{l}(3.849) \\
(0.90)^{* * *}\end{array}$ & $\begin{array}{l}0.406 \\
(0.08)^{* * *}\end{array}$ & $\begin{array}{l}-15.07 \\
(12.50)\end{array}$ & $\begin{array}{l}0.146 \\
(0.192)\end{array}$ \\
\hline Mekong River Delta & 143 & $\begin{array}{l}-21072 \\
(18339) \\
\end{array}$ & $\begin{array}{l}-0.892 \\
(0.496)^{*}\end{array}$ & $\begin{array}{l}0.742 \\
(0.11)^{* * *}\end{array}$ & $\begin{array}{l}2.608 \\
(0.37)^{* * *}\end{array}$ & $\begin{array}{l}0.606 \\
(0.16)^{* * *}\end{array}$ & $\begin{array}{l}-0.118 \\
(2.49) \\
\end{array}$ & $\begin{array}{l}0.992 \\
(0.490)^{* *}\end{array}$ \\
\hline
\end{tabular}

Source: Calculated by Author; statistically significant level: ${ }^{*} \alpha=10 \%,{ }^{* *} \alpha=5 \%$ and ${ }^{* * *} \alpha=1 \%$. 
Table 6. Impact of the Law matter in attracting FDI by region

\begin{tabular}{|c|c|c|c|c|c|c|c|c|}
\hline \multirow[t]{2}{*}{ Regions } & \multirow{2}{*}{$\begin{array}{l}\text { No. } \\
\text { Obs }\end{array}$} & \multirow[t]{2}{*}{ Cons } & \multicolumn{6}{|c|}{ GDP - Dependent Variables } \\
\hline & & & $\begin{array}{l}\text { FDI } \\
(1)\end{array}$ & $\begin{array}{l}\text { DMI } \\
(2)\end{array}$ & $\begin{array}{l}\text { GEX } \\
\text { (3) }\end{array}$ & $\begin{array}{l}\text { TRB } \\
(4)\end{array}$ & $\begin{array}{l}\text { LGR } \\
(5)\end{array}$ & $\begin{array}{l}\text { LAW*FDI } \\
(6)\end{array}$ \\
\hline $\begin{array}{l}\text { Midland and Northern } \\
\text { Mountain }\end{array}$ & 154 & $\begin{array}{l}25517 \\
(8684)^{* * *}\end{array}$ & $\begin{array}{l}-0.543 \\
(0.346)\end{array}$ & $\begin{array}{l}(0.526) \\
(0.08)^{* * *}\end{array}$ & $\begin{array}{l}1.735 \\
(0.197)^{* * *}\end{array}$ & $\begin{array}{l}-0.201 \\
(0.07)^{* * *}\end{array}$ & $\begin{array}{l}-1.105 \\
(0.682)\end{array}$ & $\begin{array}{l}1.025 \\
(0.379)^{* * *}\end{array}$ \\
\hline Red River Delta & 129 & $\begin{array}{l}-1630.5 \\
(17911)\end{array}$ & $\begin{array}{l}-0.464 \\
(0.571)\end{array}$ & $\begin{array}{l}0.630 \\
(0.11)^{* * *}\end{array}$ & $\begin{array}{l}2.900 \\
(0.385)^{* * *}\end{array}$ & $\begin{array}{l}-0.079 \\
(0.033)^{* *}\end{array}$ & $\begin{array}{l}6.748 \\
(2.14)^{* * *}\end{array}$ & $\begin{array}{l}0.473 \\
(0.551)\end{array}$ \\
\hline $\begin{array}{l}\text { North Central and South } \\
\text { Central Coast }\end{array}$ & 154 & $\begin{array}{l}-68121 \\
(9833)^{* * *}\end{array}$ & $\begin{array}{l}-0.272 \\
(0.148)^{*}\end{array}$ & $\begin{array}{l}0.462 \\
(0.08)^{* * *}\end{array}$ & $\begin{array}{l}1.074 \\
(0.109)^{* * *}\end{array}$ & $\begin{array}{l}-0.180 \\
(0.036)^{* * *}\end{array}$ & $\begin{array}{l}6.232 \\
(3.472)^{*}\end{array}$ & $\begin{array}{l}0.274 \\
\left(0.147^{*}\right.\end{array}$ \\
\hline Central Highlands & 55 & $\begin{array}{l}15364 \\
(15023)\end{array}$ & $\begin{array}{l}0.5113 \\
(2.3463)\end{array}$ & $\begin{array}{l}1.147 \\
(0.18)^{* * *}\end{array}$ & $\begin{array}{l}0.663 \\
(0.437)\end{array}$ & $\begin{array}{l}1.030 \\
(0.167)^{* * *}\end{array}$ & $\begin{array}{l}-0.607 \\
(1.598)\end{array}$ & $\begin{array}{l}0.044 \\
(2.267)\end{array}$ \\
\hline Southeast & 66 & $\begin{array}{l}-27445 \\
(66769)\end{array}$ & $\begin{array}{l}0.287 \\
(0.291)\end{array}$ & $\begin{array}{l}1.638 \\
(0.43)^{* * *}\end{array}$ & $\begin{array}{l}3.878 \\
(0.902)^{* * *}\end{array}$ & $\begin{array}{l}0.385 \\
(0.083)^{* * *}\end{array}$ & $\begin{array}{l}-13.96 \\
(12.68)\end{array}$ & $\begin{array}{l}-0.122 \\
(0.290)\end{array}$ \\
\hline Mekong River Delta & 143 & $\begin{array}{l}-16723 \\
(18445)\end{array}$ & $\begin{array}{l}-0.908 \\
(0.544)^{*}\end{array}$ & $\begin{array}{l}0.759 \\
(0.11)^{* * *}\end{array}$ & $\begin{array}{l}2.738 \\
(0.365)^{* * *}\end{array}$ & $\begin{array}{l}0.601 \\
(0.165)^{* * *}\end{array}$ & $\begin{array}{l}0.005 \\
(2.501)\end{array}$ & $\begin{array}{l}1.002 \\
(0.540)^{*}\end{array}$ \\
\hline
\end{tabular}

Source: Calculated by Author; statistically significant level: ${ }^{*} \alpha=10 \%,{ }^{* *} \alpha=5 \%$ and ${ }^{* * *} \alpha=1 \%$.

\section{Conclusion}

This paper focuses on the impact of FDI on the economic growth of the entire Vietnam and in the provinces which are differently ranked on socio-economic conditions in the period 2000 - 2010. By the fixed-effect estimation method for econometric models, the empirical result shows that FDI has strong positive impact on the economic growth of Vietnam in the period 2000-2010. Besides, the study shows that the impact of FDI on economic growth in the provinces which are ranked first is stronger than in the provinces which are ranked second (provinces and cities with worse socio economic condition). Enacting the unified enterprises law and amending the investment law in 2005 have positive effect on attracting of FDI in Vietnam, especially in the provinces which have better socio - economic conditions. On the other hand, WTO accession has positive impact on attracting FDI and exporting. Comparing the impact of WTO and Law factors on attracting FDI, the results indicate that the law factor has more positive and stronger impact on attracting FDI in Vietnam in the period 2006 - 2010. It requires the Vietnamese policy makers of to pay more attention in improving the investment climate, amending institution in order to encourage and create favorable conditions to attract as many foreign investors to Vietnam as possible. In addition, the results of the impact of FDI on economic growth in different regions of Vietnam, show that FDI has a positive impact on economic growth only exists in 4 of 6 regions including Midland and Northern Mountain region, Central Highlands region, the Southeastern region and Mekong River Delta region. An inconsistent and surprising problem which is contrary to some of the previous studies is the regions attracting more FDI will have a positive impact on it economic growth. This study finds no positive impact of FDI on economic growth in the Red River Delta region and the North Central region and Central Coast, although these two regions have density of FDI compared to the whole country is $15.22 \%$ and $39.74 \%$, respectively (Figure 2).

On the other hand, these regions not only have good socio-economic situations with a developed financial market and infrastructure system, skilled and abundant labor force but also are key economic regions of the country. Meanwhile some other areas such as Midland and Northern Mountain, Central Highlands have the proportion of FDI is very low in comparison with the national FDI. It is $1.30 \%$ and $0.43 \%$, respectively (Figure 3) but FDI has contributed significantly and positively in explaining the economic growth. This issue seems to reflects the quality of the project have a positive effect on economic growth, not the amount of registered FDI capital. It can be observed that the projects quality in the regions attracting more FDI is more inferior to others. The results of experimental studies also show that FDI has positive effects on the export promotion in Vietnam in the period 2000 - 2010. However, consideration this impact by region, FDI only has positive effects in the regions as Midland and Northern Mountain, Mekong River Delta, Southeast and Central Highlands while this effect was negative toward the Red River Delta region, North Central region and Central Coast. This study has not explained yet why there is not an impact on the economic growth in regions attracting more FDI capital while others regions with less FDI get a positive impact. Therefore, we will try to explore this problem in the near future.

\section{References}

Atrayee Ghosh Roy, \& Hendrik F. Van den Berg. (2006). Foreign Direct Investment and Economic Growth: A Time-Series Approach. Global Economy Journal, 6(1), Article 7. 
Aviral Kumar Tiwari. (2011). Foreign Aid, FDI, Economic Freedom and Economic Growth in Asian Countries. Global Economy Journal, 11(3). http://dx.doi.org/10.2202/1524-5861.1705

Borensztein, E., De Gregorio, J., \& Lee, J-W. (1998). How does foreign direct investment affect Economic Growth?. Journal of International Economic, 45, 115-135. http://dx.doi.org/10.1016/S0022-1996(97)00033-0

Bradley T. Ewing, \& Benhua Yang. (2009). The Differential Growth Effect of FDI across US Regions, International Economic Journal, 23(4), 511-525. http://dx.doi.org/10.1080/10168730903372232

Burcu Türkcan, Alper Duman, \& I. Hakan Yetkiner. (2008). How Does FDI and Economic Growth Affect Each Other? The OECD Case. International Conference On Emerging Economic Issues In A Globalizing World, Izmir.

Chew Ging Lee. (2009). Foreign Direct Investment, Pollution and Economic Growth: Evidence from Malaysia. Applied Economics, 41, 1709-1716. http://dx.doi.org/10.1080/00036840701564376

Ekanayake, E. M., \& John R. Ledgerwood. (2010). How Foreign Direct Investment affect Growth in developing countries? An empirical Investigation. International Journal of Business and Finance Research, 4(3).

Enisan Akinlo, A. (2004). Foreign Direct Investment and Growth in Nigeria An empirical investigation. Journal of Policy Modeling, 26, 627-639. http://dx.doi.org/10.1016/j.jpolmod.2004.04.011

Fedderke, J. W., \& Romm, A. T. (2006). Growth Impact and Determinants of Foreign Direct Investment in South Africa, 1956-2003.

Frimpong Joseph Magnus, \& Oteng-Abayie Eric Fosu. (2007). Bounds testing approach: An examination of foreign direct investment, trade, and growth relationships. MPRA Paper No. 352.

Har Wai Mun, Teo Kai Lin, \& Yee Kar Man. (2008). FDI and Economic Growth Relationship: An Empirical Study on Malaysia. International Business Research, 1(2).

Jai S. Mah. (2010). Foreign direct investment inflows and economic growth of China. Journal of Policy Modeling, 32(1), 155-158. http://dx.doi.org/10.1016/j.jpolmod.2009.09.001

Jean-Claude Berthélemy, \& Sylvie Démurger. (2000). Foreign Direct Investment and Economic Growth. Theory and Application to China. Review of Development Economics, 4(2), 140-155. http://dx.doi.org/10.1111/1467-9361.00083

Jonathan A. Batten, \& Xuan Vinh Vo. (2009). An analysis of the relationship between Foreign Direct Investment and Economic growth. Applied Economics, 41, 1621-1641. http://dx.doi.org/10.1080/00036840701493758

Jong Il Choe. (2005). Do Foreign Direct Investment and Gross Domestic Investment Promote Economic Growth. Global Economy Journal, 5(1).

Kyuntae Kim, \& Hokyung Bang. (2008). The Impact of Foreign Direct Investment on Economic Growth: A Case Study of Ireland. KIEP Working Paper 08-04.

Laura Alfaro Andrew Charlton. (2007). Growth and the Quality of Foreign Direct Investment: Is All FDI Equal? Conference on New perspectives on financial Globalization research department, pp. 26-27.

Laura Alfaro, Areendam Chanda, Sebnem Kalemli-Ozcan, \& Selin Sayek. (2006). How does foreign direct investment promote economic growth? Exploring the effect of financial markets on linkages. National Bureau of Economic Research, NBER Working Paper No. 12522. http://www.nber.org/papers/w12522.

Lim, Ewe-Ghee. (2001). Determinants of, and the Relation Between Foreign Direct Investment and Growth. A Summary of the Recent Literature. IMF Working Paper.

Madanmohan Ghosh, \& Weimin Wang. (2009). Does FDI Accelerate Economic Growth? The OECD Experience Based on Panel Data Estimates for the Period 1980-2004. Global Economy Journal, 9(4), 1.

Marasco, A. (2007). The Relationship between FDI and growth under economic integration: Is there one? MPRA Paper No. 5380.

Mohammad Sharif Karimi, \& Zulkornain Yusop. (2009). FDI and Economic Growth in Malaysia. MPRA Paper No. 14999.

Mottaleb, K. A. (2007). Determinants of Foreign Direct Investment and Its Impact on Economic Growth in Developing Countries. MPRA Paper No. 9457. 
Muhammad Shahzad Iqbal, Faiz Muhammad Shaikh, \& Amir Hussain Shar (2010). Causality Relationship between Foreign Direct Investment, Trade and Economic Growth in Pakistan. Asian Social Science, 6(9), 82-89.

Nguyen Phi Lan. (2006). Foreign Direct Investment and Its linkage to Economic Growth in Vietnam: A Provincial Level Analysis. Adelaide, SA 5001, Australia.

Niels Hermes, \& Robert Lensink. (2003). Foreign direct investment, financial development and economic $\begin{array}{lllll}\text { growth. Journal of Development } & \text { Studies, } & 40(1), & 142-163 .\end{array}$ http://dx.doi.org/10.1080/00220380412331293707

Okada, K., \& Samreth, S. (2010). How Does Corruption Influence the Effect of Foreign Direct Investment on Economic Growth? MPRA Paper No. 27572.

Oscar Bajo-Rubio, Carmen Díaz-Mora, \& Carmen Díaz-Roldán. (2010). Foreign Direct Investment and Regional Growth: An Analysis of the Spanish Case. Regional Studies, 44(3), 373-382. http://dx.doi.org/10.1080/00343400802508844

Oyatoye, E. O., Arogundade, K. K., Adebisi, S. O., \& Oluwakayode, E. (2011). Foreign Direct Investment, Export and Economic Growth in Nigeria. Journal of Humanities and Social Sciences, 2(1).

Parviz Asheghian. (2009). Determinants of Economic Growth in Japan: The Role of Foreign Direct Investment. Global Economy Journal, 9(3). http://dx.doi.org/10.2202/1524-5861.1509

Peter Nunnenkamp, \& Julius Spatz. (2003). Foreign Direct Investment and Economic Growth in Developing Countries. How Relevant Are Host-country and Industry Characteristics? Kiel Institute for World Economics, Kiel Working Paper, No 1176.

Piotr Misztal. (2010). Foreign Direct Investments as a factor for Economic Growth in Romania. Review of Economic and Business Studies, 3(1), 39-53.

Rui Moura, \& Rosa Forte. (2010). The Effects of Foreign Direct Investment on the Host Country Economic Growth - Theory and Empirical Evidence. FEP Working Papers, research work in progress, N0. 390.

Sajid Anwar, \& Lan Phi Nguyen. (2010). Foreign Direct Investment and Economic Growth in Vietnam. Asia Pacific Business Review, 16(1-2), 183-202. http://dx.doi.org/10.1080/10438590802511031

Samuel Adams. (2009). Foreign Direct investment, domestic investment, and economic growth in Sub-Saharan Africa. Journal of Policy Modeling, 31(6), 939-949. http://dx.doi.org/10.1016/j.jpolmod.2009.03.003

Srinivasan, P., Kalaivani, M., \& Ibrahim, P. (2010). FDI and Economic Growth in the ASEAN Countries: Evidence from Cointegration Approach and Causality Test. Journal of Management Research, 9(1), 38-63.

Stanisic, N., (2008). Do Foreign Direct Investments Increase the Economic Growth of Southeastern European Transition Economies?. South-Eastern Europe Journal of Economics, 1, 29-38.

Sumei Tang, Selvanathan, E. A., \& Selvanathan, S. (2008). Foreign Direct Investment, Domestic Investment, and Economic Growth in China: A Time Series Analysis. Research Paper No 19.

Tam Bang Vu. (2008). Foreign Direct Investment and Endogenous Growth in Vietnam. Applied Economics, 40, 1165-1173. http://dx.doi.org/10.1080/00036840600749433

Thu Thi Hoang. (2010). Does Foreign Direct Investment Promote Economic Growth in Vietnam? ASEAN Economic Bulletin, 27(3), 295-311. http://dx.doi.org/10.1355/ae27-3d

Tiwari, A., \& Mutascu, M. (2011). Economic growth and and FDI in ASIA: A panel data Approach. MPRA Paper No. 28172. http://mpra.ub.uni-muenchen.de/28172

Usha Nair-Reichert, \& Diana Weinhold. (2001). Causality tests for cross-country panels. A new look at FDI and Economic Growth in developing countries. Oxford bulletin of economics and statistics, 63(2), 153-172. http://dx.doi.org/10.1111/1468-0084.00214

Wang Shaobin, \& Wang Zhemin. (2010). Analysis on relationship between FDI and economic growth in ShaanXi based on OLS model. 3rd International Conference on Information Management, Innovation Management and Industrial Engineering.

Wasantha Athukorala, P. P. A. (2003). The Impact of Foreign Direct Investment for Economic Growth: A Case Study in Sri Lanka. 9th International conference on Sri Lanka Studies, $28^{\text {th }}-30^{\text {th }}$. 
Wu Jyun-Yi, \& Hsu Chih Chiang. (2008). Does Foreign Direct Investment Promote Economic Growth? Evidence from a Threshold Regression Analysis. Economics Bulletin, 15(12), 1-10.

Wu Yanrui. (2000). Foreign Direct Investment and Economic Growth in China. Journal of Asian Economics, 11, 471- 475. http://dx.doi.org/10.1016/S1049-0078(00)00072-5

Xiaohui Liu, Peter Burridez, \& Sinclair, P. J. N. (2002). Relationships between economic growth and foreign direct investment and trade: evidence from China. Applied Economics, 34, 1433-1440. http://dx.doi.org/10.1080/00036840110100835

Zhang-liang, M. A. (2010). Regional Economic Growth in China and the Relationship between Foreign Direct Investment Inflows: Based on 1998-2008 Panel Data. 